\title{
IDENTIFIKASI MUATAN GIZI DALAM MATA PELAJARAN DI SEKOLAH DASAR BANTARJATI 5 BOGOR
}

\author{
(Identification of Nutrition Content in Elementary School Courses \\ at Bantarjati 5 School Bogor)
}

\author{
Resty Adhistiana ${ }^{1}$, Ali Khomsan ${ }^{1}$, dan Leily Amalia ${ }^{1 *}$
}

\footnotetext{
${ }^{1}$ Departemen Gizi Masyarakat, Fakultas Ekologi Manusia, Institut Pertanian Bogor, Bogor 16680

${ }^{1}$ Departemen Gizi Masyarakat, Fakultas Ekologi Manusia, Institut Pertanian Bogor, Bogor 16680

${ }^{1 *}$ Alamat Korespondensi: Departemen Gizi Masyarakat, Fakultas Ekologi Manusia, Institut Pertanian

Bogor, Bogor 16680. Telp: 0251-8621258; Fax: 0251-8622276; E-mail: leilyamalia@yahoo.com
}

\begin{abstract}
Education and nutrition support enhance each other. Nutrition education is an important thing that have to be integrated in school's subject, because lack of knowledge regarding proper diet and healthy nutrition represents a major cause of implication in bad eating habits which can cause undernutrition among school-age children. Therefore, healthy eating habits are important to establish during childhood and sustain thereafter. The objective of this study was to identified the nutrition material that integrated in elementary school's subject. Cross sectional design was used in this study and four teacher of the fifth grade was interviewed by the researcher. The nutrition material in the subject was identified in qualitative and quantitative way. The result showed that only one topic that contain about nutrition which consist of two sub topic, human's digestion system and the relationship between food and health. The material explanation in that two sub topic is include complete type and present in sentences and also picture type. The nutrition material was quantitatively attain $37.8 \%$ compared with IGD and PUGS as justification. It can conclude that nutrition material in elementary school's subject was quite good.
\end{abstract}

Key words: nutrition material, elementary school's subject

\section{Latar Belakang}

Pangan dan gizi merupakan salah satu komponen yang sangat penting dalam pembangunan karena dapat dianggap sebagai kebutuhan dan modal dasar pembangunan serta dijadikan indikator atas keberhasilan pembangunan. Pangan sebagai sumber zat gizi (karbohidrat, lemak, protein, vitamin, mineral, dan air) menjadi landasan utama manusia untuk mencapai kesehatan dan kesejahteraan sepanjang siklus kehidupan (Karsin 2004). Adapun intake gizi yang baik berperan penting dalam mencapai pertumbuhan badan yang optimal, termasuk pertumbuhan otak yang sangat menentukan kecerdasan seseorang, sehingga akan berdampak akhir pada peningkatan kualitas sumberdaya manusia (Khomsan 2002a). Oleh karena itu, pemanfaatan makanan yang berguna untuk tubuh perlu pengetahuan gizi yang baik. Pengetahuan gizi perlu dimiliki oleh semua kalangan masyarakat, termasuk anak usia sekolah dasar sebagai generasi penerus.

Pengetahuan gizi kesehatan dapat ditingkatkan melalui berbagai strategi, salah satunya melalui pendekatan sekolah. Anak usia sekolah dasar berada pada usia pertumbuhan dan perkembangan. Walaupun tidak secepat pertumbuhan dan perkembangan pada anak remaja, anak usia sekolah dasar tetap membutuhkan konsumsi makanan yang seimbang baik jenis dan jumlahnya. Hasil penelitian Pertiwi (1998) menyebutkan bahwa anak usia sekolah dasar mengonsumsi zat gizi kurang dari kecukupan disebabkan karena jarang sarapan pagi, pemilihan makanan jajanan yang kurang baik, serta jarang mengonsumsi sayuran dan buah-buahan. Anak usia sekolah dasar mempunyai sikap yang berubah-ubah terhadap makanan. Maka kondisi yang demikian membutuhkan perhatian khusus agar makanan yang mereka konsumsi adalah makanan yang sehat dan bergizi. Pengetahuan gizi anak usia sekolah dasar tergantung pada materi yang diajarkan di sekolah.

Materi gizi kesehatan harus mulai diarahkan sejak TK dan SD, mengingat kelompok usia ini memiliki kebiasaan sikap yang masih relatif mudah dibentuk (Khomsan 2002b). Pendidikan di sekolah tidak terlepas 
dari kurikulum sebagai acuan dalam metode pengajaran yang terstruktur.

Kurikulum ialah rencana materi yang hendak disampaikan dalam satuan waktu yang telah ditetapkan untuk suatu latihan, sesuai dengan tujuan yang ingin dicapai (Suhardjo 2003). Muatan gizi dalam kurikulum yang terangkum dalam mata pelajaran di sekolah perlu diperhatikan sebagai salah satu upaya meningkatkan pengetahuan gizi anak sekolah. Syarief et al. (1988) mengatakan bahwa pentingnya pendidikan gizi bagi anak sekolah didasarkan pada dua pertimbangan. Pertama, anak usia sekolah masih mengalami pertumbuhan dengan laju yang cepat, dan anak usia sekolah adalah orang tua masa depan. Oleh karena itu keadaan gizi anak pada usia ini harus mendapat perhatian seksama agar diperoleh generasi masa depan yang berkualitas. Kedua, anak usia sekolah dapat dipandang sebagai agent of change dalam keluarga, sekurang-kurangnya dalam memperlihatkan kebiasaan-kebiasaan baru. Diharapkan bahwa bekal pengetahuan gizi yang diperoleh pada usia sekolah ini dapat diimbaskan pada anggota keluarga lainnya. Maka dari itu, perlu dilihat lebih jauh mengenai muatan gizi yang telah terintegrasi dalam mata pelajaran anak sekolah dasar.

Tujuan dari penelitian ini adalah untuk mengidentifikasi muatan gizi yang terintegrasi dalam mata pelajaran sekolah dasar.

\section{METODE}

\section{Desain, Tempat, dan Waktu Penelitian}

Desain penelitian ini adalah cross sectional study. Penelitian dilakukan di SD yang berlokasi di wilayah Kotamadya yaitu SD Bantarjati 5. Pemilihan SD secara purposive dengan pertimbangan (1) salah satu SD di kotamadya yang terdaftar di Dinas Pendidikan Bogor (2) lokasi terjangkau dan kemudahan akses. Waktu penelitian berlangsung dari bulan Mei sampai Juli 2009.

\section{Jenis dan Cara Pengumpulan Data}

Data yang dikumpulkan dalam penelitian ini terdiri atas data primer dan sekunder. Data primer diperoleh melalui hasil observasi langsung wawancara kepada empat orang guru kelas 5 yang mewakili masingmasing mata pelajaran yang memuat materi gizi. Data sekunder yang dikumpulkan adalah keadaan umum SD contoh dan buku pegangan guru yang diidentifikasi lebih lanjut mengenai muatan gizi dalam mata pelajaran.

\section{Pengolahan dan Analisis Data}

Data yang terkumpul dianalisis secara deskriptif dan statistik. Identifikasi muatan gizi dalam mata pelajaran dilakukan secara kualitatif maupun kuantitatif. Identifikasi muatan gizi secara kualitatif adalah dengan cara mengidentifikasi muatan gizi dalam buku pegangan yang dipakai oleh sekolah yang bersangkutan. Muatan gizi diukur berdasarkan banyaknya pokok bahasan yang memuat materi gizi. Adapun parameter lainnya yang digunakan adalah dengan melihat tipe uraian dan tipe penyajian. Menurut Syarief et al. (1999) tipe uraian materi pelajaran dibedakan menjadi tiga tipe yaitu tipe sekilas, tipe singkat, dan tipe lengkap. Suatu materi pelajaran termasuk tipe sekilas jika berupa kata, phrase, kalimat singkat, gambar tunggal, atau kumpulan gambar non cerita; yang termasuk tipe singkat adalah jika berupa kalimat lengkap, paragraf singkat, tabel lengkap, rangkaian gambaran cerita, atau poin-poin tanpa penjelasan; dan yang termasuk tipe lengkap adalah jika berupa paragraf lengkap atau poin-poin dengan penjelasan. Tipe penyajian materi pelajaran dibedakan menjadi dua tipe yaitu tipe kalimat, dan tipe gambar. Suatu materi pelajaran termasuk tipe kalimat jika berupa kalimat atau tabel, dan tipe gambar jika berupa gambargambar.

Identifikasi muatan gizi secara kuantitatif dalam penelitian ini adalah dengan membandingkan kesesuaian materi gizi yang terdapat dalam mata pelajaran yang diidentifikasi dengan materi Ilmu Gizi Dasar (IGD) dan Pedoman Umum Gizi Seimbang (PUGS), kemudian dinyatakan dalam satuan persen. Materi IGD tersebut yang dijadikan dasar dalam mengukur muatan gizi ini meliputi berbagai jenis zat gizi dalam cakupan zat gizi makro dan zat gizi mikro disertai fungsi, sumber, akibat defisiensi serta kelebihan dari zat gizi tersebut. Materi PUGS dijadikan sebagai tolak ukur materi menu seimbang yang terdapat dalam buku pelajaran yang diidentifikasi.

\section{HASIL DAN PEMBAHASAN}

\section{Muatan Gizi dalam Mata Pelajaran Sekolah Dasar}

\section{Identifikasi Muatan Gizi secara Kualitatif}

Harper et al. (1985) mengemukakan bahwa pendidikan gizi merupakan hal yang penting dan mutlak harus dimasukkan sebagai bagian dari kebijakan gizi dalam pembangunan 
nasional. Pendidikan gizi harus menjadi bagian integral dari pendidikan formal mulai dari Sekolah Dasar, Sekolah Menengah, dan Perguruan Tinggi. Muatan gizi yang diteliti dilihat dari materi gizi yang terdapat dalam pelajaran Ilmu Pengetahuan Alam (IPA). Pemilihan mata pelajaran tersebut adalah karena muatan yang sangat relevan dengan materi gizi adalah mata pelajaran tersebut.

Identifikasi muatan gizi secara kualitatif ini adalah dengan cara mengidentifikasi muatan gizi dalam buku pegangan yang dipakai oleh sekolah yang bersangkutan. Buku pegangan IPA kelas 5 yang diidentifikasi adalah buku IPA yang diterbitkan oleh Erlangga. Muatan gizi diukur berdasarkan banyaknya pokok bahasan yang memuat materi gizi. Adapun parameter lainnya yang digunakan adalah dengan melihat tipe uraian dan tipe penyajian. Menurut Syarief et al. (1998) tipe uraian materi pela- jaran didasarkan pada cakupan dan kedalaman materi, yang dibedakan menjadi tiga tipe yaitu tipe sekilas, tipe singkat, dan tipe lengkap. Suatu materi pelajaran termasuk tipe sekilas jika berupa kata, phrase, kalimat singkat, gambar tunggal, atau kumpulan gambar non cerita; yang termasuk tipe singkat adalah jika berupa kalimat lengkap, paragraf singkat, tabel lengkap, rangkaian gambaran cerita, atau poin-poin tanpa penjelasan; dan yang termasuk tipe lengkap adalah jika berupa paragraf lengkap atau poin-poin dengan penjelasan.

Tipe penyajian materi pelajaran dibedakan menjadi dua tipe yaitu tipe kalimat, dan tipe gambar. Suatu materi pelajaran termasuk tipe kalimat jika berupa kalimat atau tabel, dan tipe gambar jika berupa gambargambar. Berikut adalah tabel yang menyajikan muatan materi gizi berdasarkan tipe uraian dan tipe penyajian.

Tabel 1 Muatan gizi Berdasarkan Tipe Uraian dan Tipe Penyajian

\begin{tabular}{|c|c|c|c|c|c|}
\hline No. & Sub bab & & Uraian & Tipe Uraian & Tipe Penyajian \\
\hline 1. & $\begin{array}{l}\text { Alat pencernaan } \\
\text { makanan pada } \\
\text { manusia }\end{array}$ & & $\begin{array}{l}\text { Jenis proses pencernaan makanan } \\
\text { dalam tubuh: } \\
\text { - Pencernaan makanan secara } \\
\text { mekanis } \\
\text { - } \quad \text { Pencernaan makanan secara } \\
\text { kimia } \\
\text { Cara memelihara kesehatan alat } \\
\text { pencernaan, di antaranya: } \\
\text { - Makan makanan bergizi secara } \\
\text { - } \text { Mervariasi dan tidak berlebihan } \\
\text { - Makanukan pola makan teratur } \\
\text { - Kebersihan makanan dan } \\
\text { peralatan makan }\end{array}$ & Tipe lengkap & Tipe kalimat \\
\hline 2. & $\begin{array}{l}\text { Hubungan makanan } \\
\text { dan kesehatan }\end{array}$ & 2. & $\begin{array}{l}\text { Kandungan zat dalam makanan } \\
\text { bergizi, beserta fungsi dan sumber } \\
\text { dari zat-zat gizi berikut: } \\
\text { - Karbohidrat } \\
\text { - Lemak } \\
\text { - } \quad \text { Protein } \\
\text { - Mineral yang terdiri dari kalsium, } \\
\text { zat besi, fosfor, dan yodium } \\
\text { - Vitamin yang terdiri dari vitamin } \\
\text { A, B, C, D, E, dan K. } \\
\text { Menu makanan bergizi dan seimbang } \\
\text { yaitu makanan yang mengandung } \\
\text { semua zat gizi yang diperlukan oleh } \\
\text { tubuh dalam jumlah yang memadai. } \\
\text { Cara mengolah makanan dengan } \\
\text { benar: } \\
\text { - Untuk bahan mentah, } \\
\text { tahapannya adalah dicuci, } \\
\text { dipotong, dan dimasak. } \\
\text { Pengolahan sayuran sebaiknya } \\
\text { tidak terlalu matang karena } \\
\text { dapat merusak zat gizi. } \\
\text { - Kebersihan peralatan makan } \\
\text { harus dijaga }\end{array}$ & Tipe lengkap & $\begin{array}{l}\text { Tipe kalimat } \\
\text { dan gambar }\end{array}$ \\
\hline
\end{tabular}


Berdasarkan Tabel 1 di atas, dapat diketahui bahwa pokok bahasan yang memuat materi gizi dalam buku IPA yang diidentifikasi hanya ada satu pokok bahasan, yaitu Organ Tubuh Manusia dan Hewan. Muatan gizi yang terdapat di dalamnya diantaranya:

1) Sub bab Alat Pencernaan Makanan Pada Manusia yaitu proses pencernaan makanan oleh tubuh. Tipe uraian materi termasuk ke dalam tipe lengkap yaitu berupa poinpoin dengan penjelasan serta paragraf lengkap. Tipe penyajiannya termasuk ke dalam tipe kalimat. Sub bab ini juga memuat bahasan mengenai cara memelihara kesehatan alat pencernaan. Tipe uraian materi ini termasuk ke dalam tipe lengkap yaitu dengan poin-poin penjelasan. Tipe penyajiannya adalah tipe kalimat dan tipe gambar.

2) Sub bab Hubungan Makanan dan Kesehatan yang meliputi kandungan zat gizi dalam makanan bergizi, menu makanan bergizi dan seimbang, serta mengolah bahan makanan dengan benar. Tipe uraian materi ini termasuk ke dalam tipe lengkap yaitu dengan paragraf lengkap disertai poin-poin dengan penjelasan. Begitu pula dengan tipe penyajiannya yaitu tipe kalimat disertai gambar.

\section{Identifikasi Muatan Gizi secara Kuantitatif}

Identifikasi muatan gizi secara kuantitatif dalam penelitian ini adalah dengan membandingkan kesesuaian materi gizi yang terdapat dalam mata pelajaran yang diidentifikasi dengan materi Ilmu Gizi Dasar (IGD) dan Pedoman Umum Gizi Seimbang (PUGS). Materi IGD yang dijadikan dasar dalam mengukur muatan gizi ini meliputi berbagai jenis zat gizi dalam cakupan zat gizi makro dan zat gizi mikro disertai fungsi, sumber, serta defisiensi dari zat gizi tersebut. Zat gizi makro meliputi karbohidrat, protein, dan lemak, sedangkan zat gizi mikro meliputi vitamin dan mineral diantaranya vitamin $A, B$, C, D, E, dan $\mathrm{K}$ serta kalsium, zat besi, dan yodium. Materi PUGS dijadikan sebagai tolak ukur materi menu seimbang yang terdapat dalam buku pelajaran yang diidentifikasi. Materi menu seimbang dinilai sangat perlu untuk diajarkan karena diharapkan dapat digunakan sebagai pedoman praktis untuk mengatur makanan sehari-hari yang seimbang dan praktis guna mencapai dan mempertahankan status gizi dan kesehatan yang optimal. Cakupan muatan gizi secara kuantitatif dapat dilihat pada Tabel 2.

Secara umum, muatan gizi dalam cakupan zat gizi makro telah mencapai $29.1 \%$ dari materi IGD yang dijadikan tolak ukur. Materi zat gizi makro yang meliputi karbohidrat, protein, dan lemak dalam mata pelajaran belum cukup cukup lengkap. Hal ini dapat dilihat dari tidak adanya materi defisiensi dan akibat kelebihan zat-zat gizi makro tersebut. Cakupan zat gizi mikro meliputi vitamin dan mineral. Materi mengenai vitamin dinilai lebih lengkap jika dibandingkan dengan materi mineral. Hal ini dapat terlihat dari cakupan materi yang meliputi sumber, fungsi, serta defisiensi vitamin yang telah dijabarkan secara lengkap dalam mata pelajaran bersangkutan. Namun perlu diketahui, untuk fungsi vitamin masih belum spesifik. Jadi untuk cakupan materi vitamin telah mencapai $39.4 \%$ dari materi IGD yang dijadikan sebagai justifikasi. Kemudian, untuk materi mineral yang terdapat dalam mata pelajaran terkait, masih kurang lengkap, yaitu sama halnya dengan cakupan materi zat gizi makro yang tidak disertai materi defisiensi dan akibat kelebihan mineral yang dimaksud yaitu kalsium, zat besi, fosfor, dan yodium. Cakupan materi untuk mineral hanya mencapai $26.5 \%$.

Materi lainnya yang juga diukur secara kuantitatif adalah kesesuaian materi menu seimbang dibandingkan dengan PUGS. Poinpoin penting menu seimbang telah dijabarkan, namun tidak sedetail tiga belas pesan yang dimuat PUGS. Materi menu seimbang dalam buku yang diidentifikasi lebih mengarah pada pola menu 4 sehat 5 sempurna yang telah dikenal dan melekat pada masyarakat sejak dahulu. Cakupan materi menu seimbang hanya mencapai 50\%.

Secara keseluruhan, muatan gizi dalam mata pelajaran yang diidentifikasi dapat dikatakan cukup baik. Hal ini terlihat dari pencapaian materi gizi sebesar $37.8 \%$ yang diukur dengan kesesuaian dengan materi IGD yang dijadikan dasar untuk mengukur muatan gizi secara kuantitatif. 
Tabel 2 Cakupan muatan gizi secara kuantitatif

\begin{tabular}{|c|c|c|c|c|c|}
\hline Materi & Fungsi & Sumber & $\begin{array}{l}\text { Akibat } \\
\text { defisiensi }\end{array}$ & $\begin{array}{l}\text { Akibat } \\
\text { kelebiha } \\
\text { n }\end{array}$ & $\begin{array}{c}\text { Justifikasi } \\
\text { dibanding } \\
\text {-kan } \\
\text { IGD/PUGS }\end{array}$ \\
\hline \multicolumn{6}{|l|}{ Gizi makro: } \\
\hline - Karbohidrat & Sumber tenaga & $\begin{array}{l}\text { Serealia dan umbi-umbian } \\
\text { (beras, jagung, gandum, } \\
\text { kentang, ubi kayu). }\end{array}$ & Tidak ada & Tidak ada & $30 \%$ \\
\hline - Lemak & $\begin{array}{l}\text { Sumber tenaga } \\
\text { dan cadangan } \\
\text { makanan }\end{array}$ & $\begin{array}{l}\text { Lemak nabati (kelapa, } \\
\text { margarine, kacang tanah, } \\
\text { kemiri, buah alpukat) } \\
\text { Lemak hewani (daging, } \\
\text { minyak ikan susu, keju, } \\
\text { mentega, lemak hewan). }\end{array}$ & Tidak ada & Tidak ada & $28.1 \%$ \\
\hline - Protein & $\begin{array}{l}\text { Zat pembangun } \\
\text { sel-sel baru }\end{array}$ & $\begin{array}{l}\text { Protein nabati (kacang- } \\
\text { kacangan, jagung, tempe, } \\
\text { tahu, sayuran hijau) } \\
\text { Protein hewani (susu, hati, } \\
\text { ayam, ikan, udang, } \\
\text { daging, keju). }\end{array}$ & Tidak ada & Tidak ada & $29.2 \%$ \\
\hline Cakupan mu & $\tan$ gizi makro & & & & $29.1 \%$ \\
\hline \multicolumn{6}{|c|}{ Gizi mikro: } \\
\hline - Vitamin A & Zat pengatur & $\begin{array}{l}\text { Wortel, pisang, } \\
\text { sayuran segar, minyak } \\
\text { ikan. }\end{array}$ & $\begin{array}{l}\text { Rabun senja, } \\
\text { kulit kusam dan } \\
\text { kering }\end{array}$ & Tidak ada & $34.6 \%$ \\
\hline - Vitamin B & Zat pengatur & $\begin{array}{lrr}\text { Beras } & \text { tumbuk, } & \text { jagung, } \\
\text { kacang } & \text { hijau, } & \text { beras } \\
\text { merah. } & & \\
\end{array}$ & Beri-beri & Tidak ada & $30 \%$ \\
\hline - Vitamin C & Zat pengatur & $\begin{array}{l}\text { Buah-buahan kuning } \\
\text { kemerahan } \\
\text { (tomat,mangga, } \\
\text { belimbing, jeruk, sayuran) }\end{array}$ & $\begin{array}{l}\text { Gusi berdarah, } \\
\text { sariawan, bibir } \\
\text { pecah-pecah. }\end{array}$ & Tidak ada & $44.2 \%$ \\
\hline - Vitamin D & Zat pengatur & Susu dan minyak ikan. & $\begin{array}{l}\text { Penyakit tulang } \\
\text { (rakitis) }\end{array}$ & Tidak ada & $37.5 \%$ \\
\hline - Vitamin E & Zat pengatur & $\begin{array}{l}\text { Minyak kelapa, susu, } \\
\text { kecambah. }\end{array}$ & Kemandulan & Tidak ada & $35 \%$ \\
\hline - Vitamin K & Zat pengatur & $\begin{array}{l}\text { Sayur-sayuran, kacang- } \\
\text { kacangan, biji-bijian, hati. }\end{array}$ & $\begin{array}{l}\text { Darah sukar } \\
\text { membeku }\end{array}$ & Tidak ada & $55 \%$ \\
\hline - Kalsium & $\begin{array}{l}\text { Pembentukan } \\
\text { tulang dan gigi }\end{array}$ & Susu, ikan dan telur & Tidak ada & Tidak ada & $30 \%$ \\
\hline - Zat besi & $\begin{array}{l}\text { Pembentukan } \\
\text { sel-sel darah } \\
\text { merah }\end{array}$ & $\begin{array}{l}\text { Daging, hati, kedelai, } \\
\text { sayur-sayuran. }\end{array}$ & Tidak ada & Tidak ada & $25 \%$ \\
\hline - Fosfor & $\begin{array}{l}\text { Pembentukan } \\
\text { tulang dan sel- } \\
\text { sel tubuh pada } \\
\text { umumnya }\end{array}$ & $\begin{array}{l}\text { Daging, susu, biji-bijian, } \\
\text { sayur-sayuran. }\end{array}$ & Tidak ada & Tidak ada & $26.3 \%$ \\
\hline - Yodium & $\begin{array}{l}\text { Mencegah } \\
\text { penyakit gondok }\end{array}$ & $\begin{array}{l}\text { Garam beryodium dan ikan } \\
\text { laut. }\end{array}$ & Tidak ada & Tidak ada & $25 \%$ \\
\hline \multicolumn{5}{|c|}{ Cakupan muatan gizi mikro } & Menu Seimbang: \\
\hline \multicolumn{6}{|c|}{$\begin{array}{l}\text { - Anjuran mengonsumsi makanan bergizi dan bervariasi } \\
\text { - Anjuran mengonsumsi makanan untuk memenuhi kebutuhan gizi } \\
\text { - Pentingnya mengonsumsi sumber karbohidrat dan zat gizi lain } \\
\text { - Anjuran membiasakan makan pagi } \\
\text { - Anjuran minum air putih delapan gelas sehari } \\
\text { - Anjuran melakukan olahraga secara teratur } \\
\text { - Anjuran mengonsumsi makanan bersih dan aman }\end{array}$} \\
\hline \multicolumn{4}{|c|}{ Cakupan materi menu seimbang } & & $50 \%$ \\
\hline \multicolumn{5}{|c|}{ TOTAL CAKUPAN MUATAN GIZI SECARA KUANTITATIF } & $37.8 \%$ \\
\hline
\end{tabular}




\section{KESIMPULAN}

Secara kualitatif, hanya ada satu pokok bahasan yang memuat materi gizi yang terdiri dari dua sub bab. Dari kedua sub bab tersebut, tipe uraian materinya termasuk ke dalam tipe lengkap, sedangkan tipe penyajiannya berupa tipe kalimat dan tipe gambar. Secara kuantitatif, muatan gizi dalam mata pelajaran yang diidentifikasi telah cukup baik, terlihat dari pencapaian materi gizi sebesar $37.8 \%$.

\section{DAFTAR PUSTAKA}

Harper LJ, Deaton BJ, Driskel JA. 1985. Pangan, Gizi dan Pertanian. Suhardjo, penerjemah. Universitas Indonesia, Jakarta.

Karsin ES. 2004. Pengantar Pangan dan Gizi. Baliwati YF, Khomsan A, Dwiriani CM, editor. Penebar Swadaya, Jakarta.

Khomsan A. 2002a. Pangan dan Gizi Untuk Kesehatan. Jurusan Gizi Masyarakat dan Sumberdaya Keluarga. Fakultas Pertanian. Insitut Pertanian Bogor, Bogor.
Khomsan A. 2002b. Pangan dan Gizi dalam Dimensi Kesejahteraan. Jurusan Gizi Masyarakat dan Sumberdaya Keluarga. Fakultas Pertanian. Insitut Pertanian Bogor, Bogor.

Pertiwi DD. 1998. Kebiasaan Jajan dan Preferensi terhadap Makanan Jajanan Tradisional pada Anak Sekolah Dasar di 4 Desa IDT Maluku Tengah. Skripsi Sarjana Departemen Gizi Masyarakat dan Sumberdaya Keluarga, Fakultas Pertanian, Institut Pertanian Bogor, Bogor.

Suhardjo. 2003. Berbagai Cara Pendidikan Gizi. Bumi Aksara, Jakarta.

Syarief $\mathrm{H}$ et al. 1988. Model Pendidikan Gizi di Sekolah Dasar. Jurusn Gizi masyarakat dan Sumberdaya Keluarga, Fakultas Pertanian, Institut Pertanian Bogor, Bogor.

Syarief $\mathrm{H}$ et al. 1999. Laporan Akhir Studi Integrasi Muatan Pengetahuan Pangan dan Gizi dalam Pengembangan Kurikulum Sekolah Dasar. Fakultas Pertanian, Institut Pertanian Bogor, Bogor. 